\title{
Do human rights help or hinder environmental protection?
}

\author{
Conor Gearty \\ London School of Economics and Political Science, UK
}

It is acknowledged that traditional approaches to human rights can have and have had a negative impact in the field of environmental protection. But the emphasis in human rights on controlling the abuse of power and its capacity to equip social movements with a language of protest and a platform for change shows the potential for mutually beneficial connections between the two fields. The use made by environmental activists of various human rights that are to be found in international and regional laws is considered, as well as the way new social movements in the environmental arena have deployed the language of rights to promote their goals. It is concluded that a mutually reciprocal relationship between the two fields is both possible and-given the threat of climate change-essential.

Keywords: human rights, environmental protection, social movements, civil and political rights, economic and social rights

\section{THE CASE FOR HINDRANCE}

For many detached observers, the immediate response to the question our title poses would be that of course human rights hinder environmental protection. They would note as being quite natural and understandable the fact that supporters of progressive forces are invariably loath to acknowledge that there are any fundamental differences between their various causes, regardless of how different their campaigns for change appear to be. But even allowing for such intuitive solidarity, they would wonder how in this particular case such an obvious divergence on fundamentals could possibly be avoided or explained away. The subject of human rights is, as it declares for all to see in the way that it describes itself, a field that is concerned not only with humans but also with the rights that flow from being human, rather than from being anything else: not an animal (even a Great Ape) ${ }^{1}$ or a fish for example, and certainly not a tree or a habitat or a lake, no matter how (objectively) magnificent. Indeed the subject of human rights is so focused on the singular human that it has historically had a great deal of trouble even with the fact of there being more than one human around. The origins of the subject in its modern form lie in the work of scholars like Thomas Hobbes, whose vision of the individual as an autonomous entity fighting to survive in a hostile state of nature has penetrated to the core of the way the field is constructed today. ${ }^{2}$ In standard contemporary accounts of human rights from a philosophical perspective, the discussion is invariably about the self-fulfilment of the individual, his or her ability to set goals for leading a full life and then being free to go on to achieve

1. See for a good general account of the issue of animal suffering which necessarily goes beyond the language of rights A Linzey, Why Animal Suffering Matters (OUP, Oxford 2009).

2. See D Ivison, Rights (Acumen, Stocksfield 2008), especially chs 1-4. 
those targets. ${ }^{3}$ The debate is about what are the necessary building blocks of such a successful life; it is not about what that life can or ought to do to make the world around it a better place, even for others to live in, much less simply for the planet's sake.

This separateness of each and every human, one from the other, has caused human rights to struggle to create a credible theory of how humans can sensibly get along together in a way that accords with their individualistically based human rights the arguments are still being gone over today, with their modern form being in the shape of questions about how you can reconcile democracy and human rights, majority rule with judicial oversight. One of the tricks employed by human rights activists in the past to get over this problem of individual self-absorption and therefore to secure support for marginalized people - native Americans for example - has been to contrast their plight with that of animals, to the benefit of the human for sure but at a cost to the nonhuman living community, the whole point of insisting that you should not treat people like animals being that if they were animals it would be absolutely fine to exploit, beat and treat them as you desired. ${ }^{4}$ If a subject has such trouble even with the idea of extending rights to all humans, and has needed the bad treatment of animals to make moral progress, how far is it from grasping that there are more than humans out there in need of support and protection, and that beyond even the nonhuman animals there are nonsentient living things capable of imposing moral demands even at a price to the achievement of the successful life to which so much human rights work is committed?

The law on human rights provides little relief from this philosophical speciesism. ${ }^{5}$ The idea of the world outside the human as being inherently capable of belonging to the individual, and therefore as being something over which complete human mastery can be exercised, is one that is very deeply entrenched in the law in capitalist society in general and the English common law in particular. The notion of the "possessive individual' early emerged to elide property ownership with the natural rights of man, ${ }^{6}$ a combination that was then further embedded in the law and discourse of rights by its use in the revolutionary and constitutional documents which did so much to bring the idea of human rights to the fore in the modern era. ${ }^{7}$ Just as philosophy has been dogged by the challenge of universalizing the concept of individual rights, so too has law been taken up with the task of extending the legal protection of humanity to large categories of members of the species whose status has been denied despite all evidence to the contrary. It took many struggles in the course of the 19th and early 20th centuries to secure proper legal recognition of the humanity of slaves and of women, and therefore to see them as more than merely the property of their owners. ${ }^{8}$ A subject in such difficulty with the simple question of what it means to be human is unlikely to have reached the point that it can accommodate serious challenges to the ownership of nonhuman

3. J Griffin, On Human Rights (OUP, Oxford 2008) is a recent and excellent treatment of human rights from this kind of philosophical point of view.

4. B de Las Casas, In Defence of the Indians (c 1548), reprinted in part in MR Ishay, The Human Rights Reader ( $2^{\text {nd }}$ edn Routledge, New York and London 2007) 165-8.

5. See C Gearty, 'Is Human Rights Speciesist?' in A Linzey (ed), The Link Between Animal Abuse and Human Violence (Sussex Academic Press, Brighton 2009), ch 12.

6. CB Macpherson, The Political Theory of Possessive Individualism (OUP, Oxford 1962).

7. Many of which are usefully collected in Ishay (n 4), ch 15.

8. The classic example with regard to race is the US Supreme Court decision determining that slaves were in law the property of their masters, Dred Scott v Sandford 60 US 393 (1856), 60 US 393 (How). 
property, and it is indeed the case that the history of human rights law is pockmarked by its deployment in defence of liberty against regulation, even where such regulation is manifestly in the public interest. This was the case in the United Kingdom with the great health reforms of the Victorian era, and it was also evident in the rights-based resistance shown to governmental efforts to tackle capitalist excess in the United States and elsewhere. ${ }^{9}$ With increased environmental awareness leading to proposals for legislation designed to protect the environment as such, predictable legal arguments have emerged emphasising the human right to property and at very least the need for compensation before action can be taken. ${ }^{10}$ The property rights-based structure of our legal system has been a great inhibitor of action on the environmental front, and it is not unfair to characterize it as a position that is rooted in a human rights approach, not one progressives might like or share, but a human-rights-based approach nonetheless. ${ }^{11}$

International law has made a different but in some ways also problematic contribution. Of course, the human rights commitment shown by the international community, reflected in the deepening of the framework for the protection of international human rights standards, has been admirable. But it has come at a certain price, which has been the strengthening of the position of sovereign states, and in particular the integrity of the independence of governments over the geographic areas that states have been able to call their own. Human rights law is not responsible for this withdrawal of international engagement from internal affairs of course but it has been what has made it possible: respect for human rights has been the quid pro quo for national sovereignty in the global settlement achieved in the aftermath of the Second World War. ${ }^{12}$ Even the enforcement of human rights within member states has been slight, with the UN system not providing any real bite to back up the plethora of treaties that it has so enthusiastically endorsed, and outside the field of human rights (environmental protection for example) the problem of national sovereignty has been a very real one, hindering the emergence of the kind of global (or at least regional) solutions that many kinds of environmental challenges now clearly require. If an example were needed we would have to look no further than the Copenhagen talks at the end of 2009. To make matters worse, the lack of interest in the nonhuman world which is built into the philosophy of human rights, as noted above, is also evident in much of international human rights law, thereby equipping governments unconcerned about environmental protection with a human-rights-based reason for engaging in damaging activity.

This species-centred trend is exemplified by the Declaration on the Right to Development, proclaimed by the General Assembly in $1986 .{ }^{13}$ Here is a document which may have seemed like great progress when it was promulgated but in these times of anxiety about climate change and the over-exploitation of the world's resources, its ringing phrases now have what can perhaps least unkindly be called a dated ring.

9. Two of the best critiques, albeit from different perspectives, are MA Glendon, Rights Talk: The Impoverishment of Political Discourse (The Free Press, New York 1991) and JAG Griffith, The Politics of the Judiciary ( $5^{\text {th }}$ edn Fontana Press, London 1997).

10. An extreme case along these libertarian lines is developed in R Nozick, Anarchy, State and Utopia (Basil Blackwell, Oxford 1974).

11. For a regional example see Article 1 of the First Protocol of the Convention for the Protection of Human Rights and Fundamental Freedoms (European Convention on Human Rights, as amended) (ECHR), now part of United Kingdom law: Human Rights Act 1998 s 1 and sched 1.

12. A brilliant account is AWB Simpson, Human Rights and the End of Empire (OUP, Oxford 2001).

13. UNGA Res 41/128 (4 December 1986) UN Doc. A/Res/41/128. 


\section{Article 1}

1. The right to development is an inalienable human right by virtue of which every human person and all peoples are entitled to participate in, contribute to, and enjoy economic, social, cultural and political development, in which all human rights and fundamental freedoms can be fully realized.

2. The human right to development also implies the full realization of the right of peoples to self-determination, which includes, subject to the relevant provisions of both International Covenants on Human Rights, the exercise of their inalienable right to full sovereignty over all their natural wealth and resources.

\section{Article 2}

1. The human person is the central subject of development and should be the active participant and beneficiary of the right to development.

What is depressing for present purposes is that while this right to development has certainly been controversial in the human rights community, this has been mainly on account of its breadth and the degree of the obligation it places, if any, on developed countries to assist developing nations. The issue has not been about the potential damage that is done by such a profoundly human-oriented approach to the world's resources - explicable perhaps in human rights terms but worryingly narrow nevertheless. The human-rights-respecting nations began this destruction of the world just around the same time they were adopting their various rights charters, the argument runs, so why should these states be allowed now to slow down the growth of nations whose only 'fault' has been to have their own progress stymied by colonial domination? ${ }^{14}$

We can conclude this section by acknowledging that the debit side of the human rights account clearly stacks up against its value in the field of environmental protection. But this is by no means the end of the story: the subject of human rights did not achieve the trans-disciplinary power it enjoys today by being easily tied down. The phrase oozes with multiple meanings, of which we have so far only referred to three (those rooted in philosophy, constitutional law and international law). There are international relations approaches which see human rights as a tool of diplomacy and as such are neither here nor there from an environmental point of view - unless they underpin military invasions with all the astonishing environmental damage that such marauding entails (among its many other excesses). Anthropological perspectives are more benign but similarly off-centre so far as the environment is concerned, save insofar as they have assisted in the emergence of the concept of the rights of indigenous peoples, a point of important convergence between our two subject areas to which we shall return. There is one approach however which fits more comfortably than these, and which suggests that we should be careful before we write off entirely the possibility of effective support between our two fields.

\section{HELP AT HAND}

The discipline of sociology is often thought of as inimical to human rights, but in its subversion of the established fields we can detect a possible route to effective mutual reciprocity as between our two areas of enquiry. The sociological attitude to human

14. See generally M Bedjaoui, 'The Right to Development' in M Bedjaoui (ed), International Law: Achievements and Prospects (UNESCO and Martinus Nijhoff, Dordrecht 1991), ch 53. 
rights is relaxed about finding truth and happy to delink itself from the certainties of law and philosophy. It sees human rights as a term whose meaning is constructed, not discovered and which is therefore capable of change, indeed has changed over the generations, and will alter again in the future - is constantly on the move in fact. ${ }^{15}$ A core feature of this approach is concern about the abuse of power. It sees human rights as a subject which has a long and noble tradition as a galvanizer of resistance to oppression. ${ }^{16}$ Its heroes are not just the American and French revolutionaries who overthrew external and internal domination in the name of human rights but also the abolitionists and universal suffragists of the 19th century, with a special place of honour being reserved for the rebellious slaves whose courageous uprising led to the foundation of Haiti in 1804. This brand of human rights sees the term as a phrase around which positions of opposition to power can be articulated, new bonds of solidarity can be garnered and fresh versions of right and justice can be launched on a disbelieving world.

Proponents of this vibrant, fluctuating, intentionally indefinable approach to human rights are always at risk of veering into cynicism. They acknowledge that revolutions go wrong, that human rights victories can turn to defeat in the hands of human-rights-warriors-turned-despots. They recognize too that what they can do their opponents can do as well and that the powerful moreover are often better equipped (precisely because of who and what they are) to deploy the language to suit themselves. ${ }^{17}$ They know that law and philosophy can be turned against them to justify human rights abuses in the name of human rights so they are always quick (and often right) to view state action in negative terms. But what keeps them going is a belief in the power of the language of human rights to achieve radical change, to challenge real injustice and to build a new and better world. With the eclipse of socialism as the dominant progressive ideology of our time, standing up for human rights has become all the more appealing to those who in earlier generations might have been leading a Marxist guerrilla army or secretly joining the Communist Party or protesting police brutality in the name of a future workers' republic. Human rights has somehow managed to grow in prestige (part of its chameleon power no doubt) while all around it other progressive projects have been being knocked back.

Expressed in these terms, the link between human rights and environmental activism is much easier to make. Shed of its layers of philosophical and legal mystification, human rights advocacy emerges as a social movement of the very first importance. In their commitment to change, their attitude to power and in their mode of organizing, human rights groups resemble the green and environmental activists who have done so much to bring the need for environmental protection to public attention. Indeed the human rights movement could learn a great deal from the environmentalists in this regard, not least how to think about human rights. For one of the interesting aspects of comparing these two social movements is to see quite how

15. This is of course an absurdly conflated account. For a general treatment see L Morris (ed), Rights: Sociological Perspectives (Routledge, Abingdon 2006).

16. C Douzinas, Human Rights and Empire (Routledge-Cavendish, Abingdon 2007) is particularly good on this power point. The author is a lawyer albeit one with a strong sociological feel.

17. See U Baxi, The Future of Human Rights (OUP, New Delhi 2002) for an exceptionally powerful account along these lines. 
imaginatively and in tactical terms astutely the environmentalists have used the language of rights. They have been much better - more creative - than the human rights people themselves. As Neil Stammers puts it in his excellent recent study of human rights and social movements, 'activists from a wide variety of social movements have been potentially showing us how to think about human rights for a very long time'. ${ }^{18}$ Perhaps this is because the nonhuman rights community is less hidebound by the great documents from the past than is even the most imaginative human rights activist and is therefore able to be more relaxed about creative departures from the received script than his or her colleague in the orthodox human rights sphere. Or perhaps it is because other social movements are seeking to innovate and almost by definition find they have to step outside the tradition to speak interestingly in the language of rights.

Whatever might be the reason, it is clear that, in Stammers' words again, 'the green movement ... has generated a range of claims to environmental rights and environmental justice'. ${ }^{19}$ This is where we begin to see the first indicators of a convergence between human rights and environmental protection, with the running being very much made by the latter not the former community. The link between human and environmental rights was first made in 1972 at the Stockholm Conference on the Human Environment. ${ }^{20}$ This was in the first phase of the environmental movement, which was largely dissipated by the economic recession that began in 1973 and continued through much of the 1970s. It was not until the 1992 Earth Summit in Rio de Janeiro that a framework for environmental and human rights emerged, in the form of the Rio Declaration and in the Agenda 21 Plan of Action. ${ }^{21}$ Buoyed by this new interest, the UN Special Rapporteur on Human Rights and the Environment for the Sub-Commission on the Prevention of Discrimination and Protection of Minorities released an important account of the relationship between human rights and the environment, making the link between human rights abuses and environmental damage more explicitly than had ever previously been done at an official level. ${ }^{22}$ We shall come back presently to the development of international law in this field. So far as the NGO sector is concerned, this being our primary interest at this juncture, the major breakthrough was the publication in 2004 of Friends of the Earth International's Our Environment, Our Rights: Standing up for People and the Planet (the FoEI Report). ${ }^{23}$ There are a number of points of real interest about this report from a social movement point of view. They show us a method of 'doing human rights' that works from an environmental point of view.

First, there is the way in which the authors cleverly link the delivery of human rights to environmental protection: it is 'access to ... unspoiled natural resources that enable

18. N Stammers, Human Rights and Social Movements (Pluto Press, London 2009) 145.

19. Ibid.

20. See <http://www.unep.org/Documents/Default.asp?documentID=9> accessed 16 September 2009.

21. Report of the UN Conference on Environment and Development, 3-14 June 1992, Annex 1. <www.un.org/esa/dsd/agenda21/> accessed 16 September 2009.

22. Commission on Human Rights. Sub-Commission on Prevention of Discrimination and Protection of Minorities. Review of further developments in fields with which the SubCommission has been concerned: Human Rights and the Environment. Final report prepared by Special Rapporteur General, Fatma Zohra Ksentini, E/CN.4/Sub.2/1994/9.

23. See <www.foei.org/en/publications/pdfs/climate.../human_rights.pdf $>$ accessed 16 September 2009. 
survival, including land, shelter, food, water and air' ${ }^{24}$ Thus can pollution control and environmental integrity be recast as mechanisms of enforcement of human rights, standing not behind human rights as informing meta-values explaining why human rights matter (which would be impossible) but rather functioning as sine qua non conditions of existence for the realization of much of the human rights agenda. The Universal Declaration of Human Rights presupposes a functioning, human-friendly planet when it asserts the various rights to which (rather blithely we can now see) it declares all humanity to be entitled. The more fleshed-out provisions of the Covenant on Economic, Social and Cultural Rights precede the emergence of the modern environmental movement but its ambitious road map to a better world, including many of the rights highlighted in the FoEI Report, are made contingent as a matter of practicality on each State Party undertaking 'to take steps, individually and through international assistance and co-operation, especially economical and technical, to the maximum of its available resources, with a view to achieving progressively the full realisation of the rights recognised in the present Covenant by all appropriate means ... ' ${ }^{25}$ The phrase specifically emphasized here is the door through which concerns about the environment can enter the human rights calculus. But it is a small opening compared to the seemingly authorized plunder of the first sentence of Article 1.2 declaring that 'All peoples may, for their own ends, freely dispose of their natural wealth and resources without prejudice to any obligations arising out of international economic co-operation, based upon the principle of mutual benefit, and international law'. The FoEI report is right to point to the premise of a functioning planet that underpins all human rights, but (a feature this of the historical moment when the core international human rights law was being formed) it is an unspoken one, we might say today somewhat recklessly assumed. The FoEI Report reminds us that it is one of the challenges facing the social movements - of both environmental and human rights complexions - namely to force it further into the open.

The second observation to make about the Report is that it is impressively aware that '[e]nvironmental rights go hand-in-hand with civil and political rights'. ${ }^{26}$ The point is easy to miss: in the world of human rights there are these so-called 'first generation' rights which underpin the commitment of proponents of human rights to the principles of democratic government and the rule of law. Together with respect for human dignity these two principles make up the three foundations of the modern human rights movement. ${ }^{27}$ It is tempting in the environmental context to move directly to the economic and social, bypassing the civil and political as being concerned with a different set of issues. But access to courts, the ability to protest, and the capacity to obtain information are all central features of the struggle to achieve better environmental protection. This has been more obvious now than ever before, this being a time when those who care about the environmental have needed to work hard, take risks and sometimes profoundly annoy and aggravate in order to grab the world's attention. Even in democratic countries guided by the rule of law and informed by respect for human dignity, this has not been an easy matter: protest has been prohibited and then disrupted, protesters beaten, arrested, often jailed. In nondemocratic countries matters have been of course much worse. The ability to

24. Ibid 5.

25. Art 2.1.

26. See $\mathrm{n} 24$, above at 6 .

27. For further elaboration of this approach to human rights, see $\mathrm{C}$ Gearty, 'Principles of Human Rights Adjudication' (OUP, Oxford 2004) and C Gearty 'Hamlyn Lectures' [2005], Can Human Rights Survive? (CUP, Cambridge 2006). 
use the language of human rights as a shield against state power, this entitlement to declare that an unwelcome message is guarded by the civil and political rights adhering to the messenger, does important protective work in a hostile political environment, making communication both less difficult and less dangerous.

Third, there is the FoEI Report's healthily pragmatic approach to human rights, its understanding that 'the existing human rights declarations and covenants do carry significant moral weight, and can be used to bring global attention to violations happening in the most remote corners of the earth ${ }^{28}$ and that this strength can be turned to good environmental effect. Successful social movements are absolutists in the pursuit of their interests but invariably open-minded about how they can be realized. Their attitude to human rights therefore is different from that of the human rights activists: these human entitlements are more a better set of tools with which to do the job in hand than they are the job itself. Protecting human rights is the point of departure for where you want to be, not the place where you hope to arrive. It is part of the consequence of the success of the human rights movement that its minders spend so much time fighting hijackers, but there are surely worse usurpers around than the environmental movement. Like the sociologist, environmental activists see human rights as fluid and (in a good way) volatile and unstable. Unlike the lawyers they roam beyond the documentation to find new rights. Unlike the philosophers they do not pass their projects through a test rooted in historical or rational consistency. What matters is what works and what can be achieved. Thus having rehearsed the litany of standard rights, the FoEI report continues, 'We also believe in the right to claim reparations for violated rights, including rights for climate refugees and others displaced by environmental destruction, the right to claim ecological debt, and the right to environmental justice'. ${ }^{29}$ And then there is the following:

Many of these rights, particularly the political ones, are well-established and enshrined in various conventions and agreements. We can credit the establishment of some of these rights, as well as the acceptance of others that are not yet legally recognized, to the ongoing struggles of communities and indigenous peoples around the world. Other 'new' rights, including rights for climate refugees, have arisen over recent years due to the acceleration of economic globalization and the accompanying environmental destruction and social disruption. Still others, like the right to claim ecological debt, have emerged as the result of years of campaigning by Friends of the Earth and others for the recognition of the impacts of northern resource depletion and natural destruction in southern countries. All of these rights are equally important, and they are all interdependent. Environmental rights are human rights, as people's livelihoods, their health and sometimes their very existence depend upon the quality of and their access to the surrounding environment as well as the recognition of their rights to information, participation, security and redress. ${ }^{30}$

We shall come back shortly to the specifics of the rights being claimed here. But the extract stands as a classic exposition of the positive effect of combining human rights and environmental activism. In particular the idea of rights already (as it were) in the legal womb, waiting to be born, breaks the grip that the old documents have on the subject, opening it up to respond to the need for 'new rights' to reflect not changes in human nature exactly but rather alterations in the habitat in which that nature has to exist. There is also the understanding that rights flow not from the discovery of some

28. Above $\mathrm{n} 24$ at 6.

29. Ibid at 5 .

30. Ibid. 
hitherto inaccessible truth but rather from struggle and the fighting of political battles, a classic sociological insight. Once we see human rights and environmental protection as forms of activism driven by a desire to make the world a better place both for its own sake and for the sake of all who live on it (animals [including humans] among them), we can see that there are in fact close bonds between the two fields, and that human rights are a help rather than a hindrance to progress in the environmental field.

It is to a discussion of the practical way in which that help is delivered that we now turn, discussing first the various ways in which civil and political rights have been deployed to facilitate communication of the environmental message. We then consider the recent development of a range of new environmental (human) rights laws in the international arena. Following this we turn back, thirdly, to the social movements to assess the revolutionary power of human rights to assist in the radical transformation in governmental structures that many believe is urgently required (albeit almost impossible of achievement?) if the planet is to be saved for the future. The article ends with some concluding remarks about the vibrancy of the language of human rights in this field and its manifest importance in the coming crisis over climate change, at which point we suggest that not only might human rights as an idea be essential to environmental protection but that thinking about the environment might well be a key to the reinvigoration of the human rights movement as well.

\section{CIVIL AND POLITICAL RIGHTS: PROTECTING THE MESSENGER}

The rights with which we are concerned here are the civil liberties of thought, conscience, expression, assembly and association, together with the guarantees of liberty and due process. These fundamental freedoms function collectively as important protectors of activism in all political arenas. Two caveats must be entered if we want to address not only their importance but also their efficacy. First, it is a sad fact that the protection of these freedoms is in very short supply in countries that are not organized along democratic lines. There is no necessary correlation between civil liberties and democracy but the reality is that under no other system of government are such freedoms likely to thrive: the benign absolute monarch is either a daydream or a lie so far as the protection of civil liberties is concerned. Paradoxically, therefore, we find discussion of the relevance of civil and political rights restricted to those countries in which such basic freedoms are at least notionally available. This problem is compounded by the second caveat which needs also to be entered, namely that the legal enforcement of civil and political rights at the international level is very weak indeed. True there is an international covenant on civil and political rights and this even has a protocol to which states can sign up which permits quasi judicial proceedings to be launched against them for alleged infractions of the rights set out in the document. But in the absence of a world court of human rights or some analogous judicial body, ${ }^{31}$ the safeguarding of the rights set out in the covenant rests with a set of international institutions which are inevitably political in composition and possibly also on occasion partisan in the judgments that they are required to make. This is not to criticize such bodies so much as it is to observe an inevitable consequence of

31. For the limited role of the International Court of Justice and other judicial bodies organized on an international basis see G Oberleitner's Global Human Rights Institutions (Polity, Cambridge 2007), ch 6. 
their being immersed in rather than above the international politics from which they have emerged.

With avenues of true judicial redress at the international level cut off, those looking for hard evidence of the value of civil and political rights protection to the environmental movement invariably find themselves turning their gaze to regional human rights instruments, and in particular to the European Convention on Human Rights and Fundamental Freedoms, overseen by a truly independent and confident judicial tribunal, the European Court of Human Rights, based in Strasbourg in France. While it cannot be denied that the record of this court is somewhat mixed, there is no denying that at least some of its cases have done valuable work in the protection of environmental activists. A very good example is the remarkable decision of Steel and Morris $v$ United Kingdom. ${ }^{32}$ It is well known that large corporations have become increasingly adept at using aggressive legal methods to close down criticism of their activities. Such strategic litigation against private parties (SLAPP) has been especially prevalent in the environmental arena. ${ }^{33}$ But when the well-known restaurant chain McDonald's sought to use this method to silence criticism of it by a small but vocal UK environmental group, it found itself up against a couple of determined litigators who devoted their lives to defending their actions in person against the battery of legal experts deployed against them in libel proceedings in the English high court. So unequal was the adversarial strength of the two sides that the Strasbourg court later ruled the proceedings to have been an infringement of the protestors' right to fair proceedings. Given the complexity of the case and their impecuniousness, the pair had been entitled as a matter of right to legal support from the state to support their case, assistance which had not been forthcoming on account of English law's denial of legal aid in libel cases. Such a ruling was as welcome as it was unexpected: the powerful polluting companies or those who do other kinds of damage to the environment will (at least when acting within the European arena) have to build into their planning the possibility that the opponents they seek to destroy may be less weak and friendless than they appear. This is a substantial breakthrough for environmental activism.

The same Strasbourg court has also been solicitous towards certain forms of direct action, a style of protest that environmental activists have made their own. In Hashman and Harrup $v$ United Kingdom ${ }^{34}$ the applications before the court were from a couple of campaigners determined to bring to an end the practice of hunting foxes with dogs. They were seen blowing a hunting horn and generally making noises with a view to disrupting the activities of the well-known Portman Hunt. One of the more repressive of English law's informal mechanisms for clamping down on dissent was wheeled into action against them: they were not arrested but rather brought before magistrates where they were duly required to keep the peace and be of good behaviour for 12 months on pain of a $£ 100$ fine. The Crown Court dismissed their appeal against this order - despite there having admittedly been no breach of the peace, the defendants had interfered with the hunt and would do so again and so had acted in a way that was (in the ancient Latin required by this medieval law) contra bonos mores (against good morals). To its credit Strasbourg was having none of this nonsense, condemning the jurisdiction as too vague to operate as a lawful inhibition of free speech. Sixteen of the seventeen judges thought indefensible the idea that you

32. (2005) 41 EHRR 403.

33. See F Donson, Legal Intimidation (Free Association Books, London 2000).

34. (1999) 30 EHRR 241. 
could be condemned for behaviour which was merely 'wrong rather than right in the judgment of the majority of contemporary fellow citizens'. Of course this takes us to the nub of the matter. Times have now changed in Britain. The laws sought by Hashman and Harrup have been achieved. It is the hunting, not opposition to it, that is fast becoming contra bonos mores. And more broadly, as a result of the Hashman and Harrup case, this oppressive jurisdiction is no longer available to prosecutors or magistrates who wish to stifle change in the interests of yesterday's assumptions about right and wrong.

These have been good decisions but the sociologist in all of us warns against overreliance on judges. In Steel and Others $v$ United Kingdom ${ }^{35}$ by way of a necessary precautionary contrast, efforts by different sets of activists on unrelated occasions to disrupt a hunt and the construction of a proposed motorway led to binding over orders requiring the defendants to keep the peace, with the European Court finding that in each case the arrest and detention of the protestors had been justifiable. The ancient common law jurisdiction of breach of the peace, through which the binding over orders had been imposed, was held to provide 'sufficient guidance' and the right 'degree of precision' to meet the Convention's insistence that restrictive laws be clear and accessible to all. An even more disappointing decision is that of the littleknown Appleby $v$ United Kingdom ${ }^{36}$ in which efforts by campaigners to assert their right to take their antidevelopment message into the local shopping mall proved unsuccessful, with the Court agreeing that the centre was technically private property and therefore subject to whatever entry requirements the owners might care to make which certainly did not include a right to protest on their premises. It is very regrettable that the judges did not use this case to address the fact that so much protest that is needed today, particularly in the environmental field, needs to take place on private property. When bustling commercial environments are foreclosed to the demonstrator, it will not be enough to be told that the empty high street is available. The downside of these decisions, of course, and it is always a risk when radicals resort to law, is that defeat legitimizes a practice which may once have been doubtful but which now, basking in judicial approval, quickly becomes routine.

The value of civil and political rights to the environmental movement probably lies more in the fact of their acceptance within a culture than in any particular decision of this or that human rights court. One or two exceptional decisions aside, the legal tool is more often a reflection of a culture rather than a maker of it. The assertion of civil and political rights give activists a universal language - understandable even to those who do not share their substantive concerns - with which to fight back against a state intent on silencing them. Because of their central position in human rights law, civil and political rights are usually more open to legal avenues (national and regional) than are other rights, and inevitably this has tempted some activists to seek to smuggle their true goals into law cases camouflaged as traditional legal actions concerned only with civil rights. This worked well for a while in Strasbourg where serious problems of pollution about which (in the two leading cases) the Spanish and Italian governments were doing nothing led to successful litigation under the European Conventions guarantee, in Article 8, of the right to respect for private and family life. ${ }^{37}$ But the Court then overreached itself, in 2001 in the well-known case of Hatton v United Kingdom. In the first decision of that name, heard before a chamber of seven judges, the Court

35. (1998) 28 EHRR 603.

36. (2003) 37 EHRR 783.

37. Lopez Ostra v Spain (1994) 20 EHRR 277; Guerra v Italy (1998) 26 EHRR 357. 
(by a majority of five to two) held that the effort by the authorities to improve the night noise climate around Heathrow airport had not been adequate for Article 8 purposes and that consequently the state had 'failed to strike a fair balance between the United Kingdom's economic well-being and the applicants' effective enjoyment of their right to respect for their homes and their private and family lives'. ${ }^{38}$ This produced both a powerful dissent from the British judge (Sir Brian Kerr) and a strongly adverse reaction in Britain. Unusually, the United Kingdom government referred the case to a Grand Chamber of 17 judges as the European Court rules allowed it do and by a majority of twelve to five this larger Court resiled from its earlier ruling, stressing the primacy of the local, democratically legitimate decision-maker and the especial need for the Strasbourg bench to be sensitive on matters of general policy. ${ }^{39}$ Environmental protection needs a more direct guarantee in human rights law than can be provided by the right to privacy or by civil and political rights generally. Does international law provide one?

\section{AN INTERNATIONAL RIGHT TO ENVIRONMENTAL PROTECTION?}

Agenda 21, the Rio Declaration on Environment and Development and the Statement of Principles for the Sustainable Management of Forests were adopted by the United Nations Conference on Environment and Development, the famous Rio Conference referred to earlier, held in $1992 .^{40}$ The first principle declared that 'Human beings are at the centre of concerns for sustainable development. They are entitled to a healthy and productive life in harmony with nature'. Much of the Declaration is concerned with controlling the impact of sovereign power and the right to development so as to build in some environmental sensitivity into their mode of operation. Principle 5 has a strong human rights dimension: 'All States and all people shall cooperate in the essential task of eradicating poverty as an indispensable requirement for sustainable development, in order to decrease the disparities in standards of living and better meet the needs of the majority of the people of the world'. In terms of explicit human rights, however, the closest the document gets is when it asserts entitlements to information in Principle 10. There is also this anticipation of a strong future human rights trend in Principle 22:

Indigenous people and their communities and other local communities have a vital role in environmental management and development because of their knowledge and traditional practices. States should recognize and duly support their identity, culture and interests and enable their effective participation in the achievement of sustainable development.

It is perhaps understandable that the finalized declaration did not include any generalized 'right to a good environment' - it is hard to see what credibility such an assertion would have enjoyed and its appearance may well have added little to what was already being addressed. The report of the Special Rapporteur on Human Rights and the Environment, Mrs Fatma Zohra Ksentini, in July 1994, did include a draft Principle to the effect that '[a]ll persons have the right to a secure, healthy and ecologically sound environment' and that '[t]his right and other human rights, including civil, cultural, economic, political and social rights, are universal, interdependent and

38. (2001) 34 EHRR 1 para 107.

39. (2003) 37 EHRR 611.

40. See n 21, above. 
indivisible' (Principle 2 in Annex 1). ${ }^{41}$ The report also asserted that '[a]ll persons have the right to an environment adequate to meet equitably the needs of present generations and that does not impair the rights of future generations to meet equitably their needs' (Principle 4).

Viewed overall, however, less progress in this generalized field has been achieved than might perhaps have been first thought possible in the early 1990s. It is true that Article 24 of the African Charter on Human and Peoples' Rights states that '[a]ll people shall have the right to a general satisfactory environment favourable to their development'. The Additional Protocol to the American Convention on Human Rights (San José, 1969), which relates to economic, social and cultural rights, adopted at San Salvador in 1988, also contains a clause concerning the right to an environment, Article 11 providing that 'everyone shall have the right to live in a healthy environment and to have access to basic public services', the states parties then being required to promote the protection, preservation, and improvement of the environment'. The Convention on the Rights of the Child, dated 20 November 1989, explicitly refers to the need for the education of the child to be directed, inter alia, to 'the development of respect for the natural environment' (Article 29, para. (e)). But this hardly amounts to a strong momentum towards a new legal framework.

The UN Declaration on the Rights of Indigenous Peoples, adopted by the General Assembly in September 2007, provides protection for the environment in the timehonoured human rights way of looking at habitat through people. ${ }^{42}$ One of the driving forces behind this declaration was the realization, acknowledged in its preamble, 'that respect for indigenous knowledge, cultures and traditional practices contributes to sustainable and equitable development and proper management of the environment'. The document itself has plenty of good things to say about fostering these communities, seeking to protect them before destruction becomes their way of life as well. Article 29 is most specific about the linkage between the two:

1. Indigenous peoples have the right to the conservation and protection of the environment and the productive capacity of their lands or territories and resources. States shall establish and implement assistance programmes for indigenous peoples for such conservation and protection, without discrimination.

2. States shall take effective measures to ensure that no storage or disposal of hazardous materials shall take place in the lands or territories of indigenous peoples without their free, prior and informed consent.

3. States shall also take effective measures to ensure, as needed, that programmes for monitoring, maintaining and restoring the health of indigenous peoples, as developed and implemented by the peoples affected by such materials, are duly implemented.

We may conclude that the overall international human rights law record in this field is pretty modest. This is not necessarily a bad thing in itself. The risk in too much apparent success in this sphere is that the right to environmental protection joins the ranks of those other human rights guarantees which are more honoured in the breach than in the observance, with weak governmental commitment and ineffective enforcement structures combining to make the supposed advance worse than useless.

41. See $\mathrm{n} 22$, above.

42. UNGA Res 61/295 (13 September 2007). 


\section{DOING HUMAN RIGHTS}

Lest it be thought that the last section ended on too dismal, perhaps even too cynical a note, the sociological insight into human rights that has been at the heart of this essay needs to be recalled: you do not have to succeed in achieving a new law to have triumphed in your deployment of the language of human rights. The legal arena is not the only test of utility. Nowhere is this clearer than in relation to environmental protection. We have already seen in the FoEI Report how valuable the language of human rights can be made to be in the hands of a campaigning organization. There is a radical, transformative power here, rooted in the emancipatory history of these words, that fits well with the goals of many environmental movements, those groups for whom winning this or that case is neither here nor there. What has been interesting has been how the idea of human rights has been appealing to radical critics of capitalism who want at the same time to frame their opposition in terms that are not traditionally Marxist in approach. One of the key drivers of this brand of thinking and doing have been the Zapatistas, for whom the claims of their people (the indigenous people of Chiapas) have long been articulated in rights terms. Their declarations have spoken of the 'inalienable right' of the people 'to alter or modify their form of government' and their actions have been justified on account of the 'impossibility of struggling peacefully for our elemental rights as human beings'. ${ }^{43}$ What is appealing here is the use of language that makes sense to the powerful as a way of driving home the injustice over which they preside and which has flowed out of earlier revolutionary action which has been rooted in exactly the same kind of arguments. It is much harder for the rich to deny than plaintive calls for the workers of the world to unite and cast away their chains in the pursuit of socialist Nirvana.

The World Social Forum which has been developed in an explicit contrast with the World Economic Forum and which has over the years generated regional spin-off versions of itself has seized on human rights as an effective communicative tool. Among its Charter of Principles are the following:

10. The World Social Forum is opposed all totalitarian and reductionist views of economy, development and history and to the use of violence as a means of social control by the State. It upholds respect for Human Rights, the practices of real democracy, participatory democracy, peaceful relations, in equality and solidarity, among people, ethnicities, genders and peoples, and condemns all forms of domination and all subjection of one person by another.

11. As a forum for debate the World Social Forum is a movement of ideas that promotes reflection, and the transparent circulation of the results of that reflection, on the mechanisms and instruments of domination by capital, on means and actions to resist and overcome that domination, and on the alternatives proposed to solve the problems of exclusion and social inequality that the process of capitalist globalization with its racist, sexist and environmentally destructive dimensions is creating internationally and within countries. $^{44}$

Here we have in summary why human rights as a term comes so much to the fore when its supposed precision by reference to the disciplines (in both senses) of philosophy and law is junked and in their place is put a much vaguer but more urgent awareness of a

43. The Second Declaration from the Lacandona Jungle (adopted 19 June 1994) <http://flag. blackened.net/revolt/mexico/ezln/ccri_2nd_dec_june94.html> accessed 17 September 2009.

44. See $<$ http://www.wsfindia.org/?q=node/3> accessed 17 September 2009. 
need for action to combat manifest injustice. The radicalism and idealism of Marxism remains, but now equipped with the ethical imperative of buttressing universal human dignity (in all its fragile manifestations) rather than the altogether more confident (albeit desiccated) dialectical materialism that drove the revolutionaries of past generations. It speaks meaningfully across the whole spectrum of a community, from the weak across to the powerful, deploying the convictions of the latter - rooted in the battles of the past - to force recognition of the need for similar struggles today. At the right level of generality, fighting for human rights can be a transformative project as well as a conciliatory one, appealing to those who seek to build a new world order, as well as to those who want to construct coalitions across political divides. This chameleonism is often a source of frustration for sure, but it is what gives the idea of human rights the power that it undeniably enjoys in the world today.

\section{CONCLUSION: MUTUAL RECIPROCITY AS A NECESSARY FUTURE}

The need to bring the environmental and human rights movements together has been rendered both urgent and vital by the impending climate change catastrophe. For just as the human rights protagonist has often given the impression that he or she does not care about the natural world, so too have some environmentalists seemed at times to despise people. There is in such activists a potential casualness about humankind which may be understandable emotionally (it is our reckless species which has brought us to the verge of collapse) but which when worked through into policies and positions will - if left unchallenged - invariably involve the poor and the vulnerable (whose personal responsibility for environmental change is nonexistent) paying a heavy price for the polluting and destructive recklessness of others. It will be the Maldives that disappears, the Bangladeshi millions who will find their homes inundated, and the Inuit whose habitats will be destroyed. To put this another way, an approach to meeting the climate change challenge which is indifferent to human suffering will inevitably lead to decisions in which the world's poor are once again made to pay a price for the selfishness of others. The human rights approach can stop this happening. By focusing on equality and respect for individual dignity, an insistence on attention to human rights has the effect of forcing all decision-makers to look outside their own circle, to see the human as well as the global consequences of their actions. ${ }^{45}$ It is an essential ethical component of a proper response to climate change. ${ }^{46}$

And what can the environmentalist offer human rights in return? The problem with all branches of human rights is lack of confidence in the foundations of the subject. There are historical reasons for this: a commitment to equal dignity made sense when the field was dominated by an explicitly Judeo-Christian ethic, but in the postreligious world (where most human rights activism is to be found) this theological basis for belief in equality is much harder to sustain. Why are we all equal? Why should not one be favoured over the other? Where does this morality come from, if not from

45. As the Commonwealth Secretariat neatly puts it in its title to a recent intervention: Human Rights and Climate Change: An Approach That Puts People in the Forefront of the Debate Commonwealth Secretariat Discussion Paper 5 (July 2009).

46. See generally International Council on Human Rights, Climate Change and Human Rights: A Rough Guide (International Council on Human Rights Policy, Versoix 2008); and S Humphreys (ed), Human Rights and Climate Change (Cambridge University Press, Cambridge 2010). 
God and His representatives on earth? What is so wrong about abusing power if you are lucky enough to have it? Human rights thinkers are far from being able to answer these questions effectively, but thinking hard about the embedded nature of humans in the world around them at least points the enquiry in the right direction. It is only through reflecting upon our species as a part of the natural world that we can come to a renewed sense of the wonder of our existence and the beauty (as well as the immense productivity) of our seemingly innate propensity to think about others as well as solely about ourselves and our kin. And if we can expand our horizons to include an imaginative leap beyond the living into the realm of the billions of as yet unborn (indeed not-yet-conceived) humans of the future, we will be able to see that here is a vast category of the powerless who demand our attention. ${ }^{47}$ Our empathy with the other is one of our finest attributes and it is through the language of human rights that it finds a highly effective because universal form of contemporary expression. But its innateness does not mean that its manifestation cannot be greatly reduced by the social situation in which it finds itself. The survival of our species without the loss of our precarious commitment to goodness is surely enough of a foundation for human rights today.

47. See further C Gearty, 'Can Human Rights Survive?' above n 27, ch 5 and on evolution and human rights 'Human Rights After Darwin: Is a General theory of Human Rights Now Possible?' at <http://www.conorgearty.co.uk/pdfs/Human_Rights_after_DarwinLECTURE7May2009.pdf> accessed 17 September 2009. 